\title{
An artificial membrane for in vitro feeding of Varroa jacobsoni and Acarapis woodi, mite parasites of honey bees*
}

\author{
WA Bruce $1^{* \star}$, RB Henegar 2, KJ Hackett 2 \\ 1 Bee Research Laboratory Agricultural Research Service Bldg 476, \\ BARC-East Beltsville, MD 20705; \\ 2 Insect Biocontrol Laboratory Agricultural Research Service Bldg 465, \\ BARC-East Beltsville, MD 20705, USA
}

(Received 26 March 1991; accepted 27 June 1991)

\begin{abstract}
Summary - A synthetic membrane through which Varroa jacobsoni Oudemans, a mite parasite of honey bees, can be fed was modified in such a manner that seams could be made virtually leakproof and sacs designed to almost any configuration. These modifications thus eliminated problems encountered in previous feeding studies. In addition, another parasitic mite of honey bees, Acarapis woodi (Rennie), the tracheal mite, was also able to penetrate this membrane and ingest an artificial medium. Membrane modification and sac preparation are discussed in detail.
\end{abstract}

Varroa jacobsoni / Acarapis woodi/ rearing medium / feeding / in vitro

\section{INTRODUCTION}

Researchers who wish to rear, in vitro, ectoparasitic blood-sucking arthropods are very often thwarted by lack of adequately developed rearing systems. A strategy often used is to feed ectoparasites through a membrane. However, suitable membranes have not always been found. Various materials have been used for different organisms with varying degrees of sucess and have included silk bolting cloth (Whar- ton and Cross, 1957), silicone sealer (Butler et al, 1984), plastic films such as Handiwrap (Bruce, 1989), microencapsulated plastics (Anon, 1971), Parafilm ${ }^{\circledR}$ (Bruce et al, 1988) and paraffin wax (Hagan and Tassan, 1965), as well as others (Crystal, 1986).

Each material has advantages and disadvantages depending on use and these will, in some respect, differ with each organism. Ideally, a material should be: (i) easy to handle; (ii) inexpensive; (iii) avail-

\footnotetext{
* This article reports the results of research and mention of a proprietary product and does not constitute an endorsement or a recommendation for its use by the USDA.

** Correspondence and reprints.
} 
able; (iv) strong, but penetrable; (v) adaptable to the desired configuration; and (vi) heat sealable.

In 1985 it was decided by the European Economic Community Research Committee on Varroatosis and the United States Department of Agriculture, Agricultural Research Service to determine whether Varroa jacobsoni Oudemans, a blood-sucking mite parasite of honey bees, could be reared in vitro on an artificial diet developed for another mite, Pyemotes tritici (Lagreze-Fossat and Montane) (Bruce, 1989). The rationale for such a project was that, if the mite could be reared in vitro, certain aspects of its behavior could be more easily studied and various strategies for control, based on toxicants or hormonally active chemicals added to the diet of the bee might be realized. Initially, several membranes were tested with no success. Subsequently, stretched Parafilm ${ }^{\circledR}$ was determined to be most satisfactory (Bruce et al, 1988). The results of this research, conducted during a 4-month period at the University of Udine (Udine, Italy) were quite successful; all feeding stages of the mite were able to penetrate the membrane and feed on an artificial diet. However, the major concern was an inability to seal the membrane without causing leaks and tears.

Since that time Italian researchers (personal communication; N Milani, Udine) have tested many other membranes, none of which proved more statisfactory than the stretched Parafilm ${ }^{\circledR}$. With the discovery of $V$ jacobsoni in the United States in September 1987, work began in late 1988 at the US Department of Agriculture, Beneficial Insects Laboratory, Beltsville, to continue the original effort to rear $V$ jacobsoni in vitro. The present study was initiated to determine if the Parafilm ${ }^{\circledR}$ could be modified or improved such that its routine use would be assured for $V$ jacobsoni as well as another blood-sucking ectoparasite of honey bees, Acarapis woodi (Rennie). Because $A$ woodi imbibes very little hemolymph and does not exhibit physogastry, it was anticipated that a different kind of assay might have to be developed to demonstrate that penetration and feeding activity had taken place. Various assays are available. For example, $P$ tritici, upon uptake of hemolymph, exhibits physogastry within 8$24 \mathrm{~h}$, with the abdomen eventually swelling up tremendously $(0.5-1.0 \mathrm{~mm}$ diameter) (Bruce, 1989). Diets can be dyed and, in a relatively large mite such as $V$ jacobsoni, the gut (or feces) can be easily observed for color differences. However, to determine whether or not food uptake had occurred in a mite as small as $A$ wood $i$ (150 $\mu \mathrm{m}$ length), a mite that only takes up minute quantities of hemolymph, an indirect assay was used, which employed a microbial indicator.

\section{MATERIALS AND METHODS}

\section{Source of honey bees}

Brood combs from honey bee colonies known to be heavily infested with $V$ jacobsoni were transported under quarantine from an apiary near $\mathrm{Co}$ coa Beach, FL, to the ARS quarantine facility at the Bee Research Laboratory, Beltsville, MD. Combs were kept in an incubator at $27 \pm 1{ }^{\circ} \mathrm{C}$, $60 \% \mathrm{RH}$.

Honey bees were removed from colonies infested with $A$ woodi, maintained at the $\mathrm{Bee} \mathrm{Re}$ search Laboratory, Beltsville. Approximately 50 bees were kept in the laboratory on a diet of water and sugar syrup.

\section{Preparation of parafilm membranes}

Membranes were prepared using rolls $(10 \mathrm{~cm}$ wide) of Parafilm ${ }^{\otimes}$ (American Can Co, Neemah, 
WI). A 5-cm strip $(5 \times 1 \mathrm{~cm})$ was cut and laid on 2 glass microscope slides positioned at the ends of the film. Two additional microscope slides were placed over the bottom slides forming a "sandwich" with the Parafilm $\otimes$ (fig 1A). With one set of slides in each hand, the film was stretched slowly until the tension stopped the pull, at a Parafilm ${ }^{\circledR}$ length of $\approx 30 \mathrm{~cm}$. Next, the film between the slides was cut from one end and removed from the strip. A glass slide was then positioned perpendicular to the strip and the previously cut end of film was folded over this slide $1-1 / 2 \times$ the width of the film and cut (fig 1B). The slide could now be used as a holder for the Parafilm to facilitate the heat-sealing of the edges. An Accu-Seal Corporation (San Diego, CA) bar-type heat sealer (Model 10121), at a timer setting of $\approx 1(1.0 \mathrm{~s})$, was used to seal 2 of the 3 open sides (fig 1C). Next, a wax paper strip was inserted between the glass slide and the Parafilm ${ }^{\circledR}$ sac. Glass slides were again placed at the ends of the sac and the film stretched in the unstretched direction as before (fig 1D). The glass slides at the open end were removed, a pipette was inserted in front of the wax paper strip, and a quantity of medium introduced into the sac. Prior to the placement of the medium, the sac could be further expanded in all directions, by the careful introduction of a small quantity of compressed gas (EFA-duster, EF Fullam Inc, Schenectady, NY). The remaining open side of the sac was then heat sealed. Care should be taken not to introduce air bubbles into the medium or to spill medium along the sides of the sac which may result in an inadequate heat-seal being made.

\section{Diet medium and feeding of mites}

The medium used was modified insect tissue culture medium, Medium M1D (Whitcomb, 1983). For feeding trials, the medium contained a microbe (bacterium Spiroplasma melliferum Clark et af) which, if imbibed by the mites, could be reisolated from the mites by crushing them into sterile M1D medium (without bacteria). If the mites had in fact imbibed the bacteria, the diet would change color in 2-3 days as a result of a change in $\mathrm{pH}$ as nutrients were depleted by the bacteria.
Adult female $V$ jacobsoni were removed from the brood cells as needed and were kept in $\mathrm{Ni}$ tex stoppered glass tubes. The tubes were placed in desiccators over a saturated salt solution of $85 \% \mathrm{RH}$ in an incubator at $27 \pm 1^{\circ} \mathrm{C}$ for 2-4 h. Six to 8 mites were then placed on a M1D-filled sac in a closed Petri dish for 3 days.

Adult female $A$ woodi were removed from honey bee tracheae in a manner described previously (Smith, 1987) and placed directly onto an M1D-filled sac and placed in a closed Petri dish for 3 days.
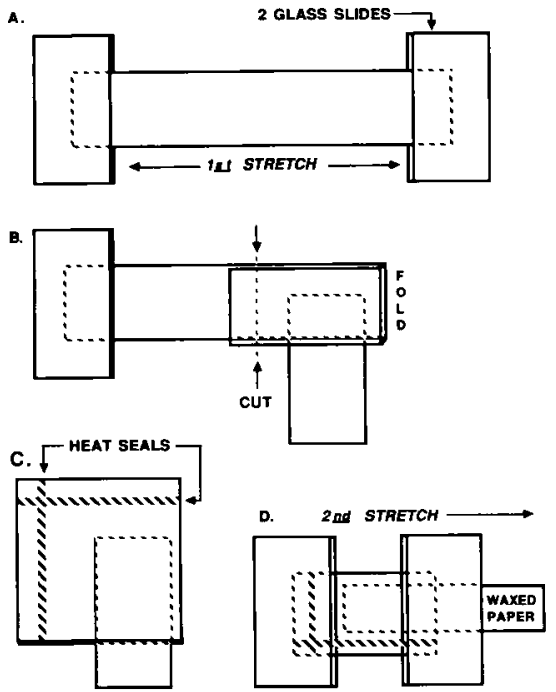

Fig 1.A. A $5 \times 10 \mathrm{~cm}$ strip of Parafilm is placed between glass microscope slides and pulled or stretched until tension stops the pull or to $\approx 30$ $\mathrm{cm}$. B. One end is released from the slides and folded over a glass slide and cut with scissors. C. 2 of the 3 sides are heat-sealed. D. The glass slide is removed and a length of waxed paper inserted into the sac. The sac is placed between glass slides and stretched in the previously unstretched direction. The sac can now be filled with medium or stretched further "balloon" fashion with compressed gas, filled with medium and then heat sealed. 


\section{RESULTS AND DISCUSSION}

Microscopic examination of the stretched Parafilm ${ }^{\circledR}$ to determine thickness revealed that a thickness of $\approx 10 \mu \mathrm{m}$ could be obtained routinely. While the gnathosomas of these mites differ considerably, the effective length of the mouthparts necessary for penetration is about the same, or $15 \mu \mathrm{m}$.

Although the number of mites of each species tested was small ( 5 each of 2 species), all tested positive for the microbial indicator upon microscopic examination (Zeiss, dark field microscopy 1250x), of the squashed mite preparations, and upon inoculation of these preparations into sterile M1D medium. A more complete and detailed discussion of the laboratory use and some possible biological implications of the microbe in both natural populations of honeybees and mites is given elsewhere (Bruce et al, 1991). These results clearly demonstrate 2 important points: 1), artificial diets can now be contained within a membrane that can be made suitably thin, in almost any configuration, and with heatsealed seams that are extremely strong and virtually leak-proof; and 2), $A$ woodi can penetrate a synthetic membrane and feed on an artificial medium. In addition, it is quite probable that this modified membrane could be used for the in vitro feeding of other arthropods as well (eg Ornithonyssus sylviarum (Canestrini and Fanzago), northern fowl mite; J Carroll, personal communication, USDA, Beltsville, July 1990). At this point little can be said about the nutritional requirements of either $V j a$ cobsoni or $A$ woodi, but one fact is clear: a membrane and mechanism are now available to test various artificial diets and to develop strategies for the eventual control of these mite parasites of honey bees.
Résumé - Une membrane artificielle pour le nourrissement in vitro de Varroa jacobsoni et Acarapis woodi, acariens parasites de l'abeille. Une membrane synthétique, au-travers de laquelle l'acarien parasite des abeilles Varroa jacobsoni peut être nourri, a servi à fabriquer des sacs de différentes formes, et totalement étanches. Ces membranes ont été réalisées en utilisant du Parafilm ${ }^{\circledR}$. Une bande de $5 \mathrm{~cm}$ a été coupée et déposée sur 2 lames de verre pour microscope, chacune à l'une des 2 extrémités du film. Deux autres lames identiques ont été déposées sur les 2 précédentes, et avec les 2 lames dans chaque main, le film a été étiré lentement jusqu'au maximum. Le film situé entre les lames a alors été coupé à une extrémité et enlevé de la bande. Une lame de verre a été ensuite positionnée perpendiculairement à la bande, et l'extrémité préalablement coupée du film a été pliée sur cette lame, d'une fois et demie la largeur du film, et coupée (fig 1B). Un appareil chauffant, pour sceller les sacs, a été utilisé pour fermer 2 des 3 côtés ouverts (fig 1C). Une bande de papier ciré a été déposée dans le sac et le film a été étiré, à nouveau en utilisant des lames de verre, dans la direction non encore étirée (fig 1D). De plus, le sac a été davantage étiré grâce à de l'air comprimé. Après introduction de milieu nutritif, le dernier côté ouvert du sac a été scellé par la chaleur.

Varroa jacobsoni / Acarapis woodi / milieu d'élevage / alimentation / in vitro
Zusammenfassung - Eine künstliche Membran zur experimentellen Fütterung der parasitischen Bienenmilben Varroa jacobsoni und Acarapis woodi. Eine synthetische Membran, durch welche die 
parasitische Milbe Varroa jacobsoni Oudemans ernährt werden kann, wurde derart verändert, daß wasserdichte Nähte angelegt und Säcke in fast jeder Form gebildet werden konnten. Als Membran wurde $\mathrm{Pa}$ rafilm ${ }^{\circledR}$ benutzt. Es wurden Streifen von 5 $\mathrm{cm}$ Länge geschnitten und mit ihren Enden über zwei Mikroskop-Objektträger gelegt. Dann legte man zwei weitere Objektträger über die unteren (mit der Membran dazwischen), faßte jedes Paar der Glaspatten mit einer Hand und dehnte den dazwischengespannten Film so weit aus als möglich (Abb 1A). Der Film zwischen den Objektträgen wurde dann an einem Ende abgeschnitten und von dem Streifen abgetrennt. Als nächster Schritt wurde ein Objektträger rechtwinklig über den Streifen gelegt und das vorher abgeschnittene Ende des Films 11/2 mal der Filmbreite um diesen Objektträger gefaltet und abgeschnitten (Abb 1B). Ein stabförmiges Versiegelungsgerät wurde zur Versiegelung von zwei der drei offenen Seiten benutzt. Dann wurde ein Streifen eines Wachspapiers in die Tasche geschoben und der Film wieder mit Hilfe von Objektträgen ausgedehnt, diesmal in der anderen Richtung (Abb 1D). Diese Tasche kann jetzt zusätzlich durch Einblasen von Preßluft weiter gedehnt werden. Nach Einfüllen des nötigen Quantums der Nährlösung wird die verbliebene offene Seite der Tasche hitze-versiegelt. Die mikroskopische Untersuchung des gedehnten Parafilms ergab eine durchschnittliche Dicke von $10 \mu$. Das ist ausreichend dünn, um von Mundwerkzeugen der Milben durchstochen zu werden. Als Nährflüssigkeit wurde des Medium M1D benutzt, das als Kulturmedium für Insektengewebe verwendet wird. Zum Nachweis der Aufnahme der Nährflüssigkeit durch die Milben durch die Membran hindurch wurde diese vorher mit Bakterien versetzt. Nach drei Tagen Fütterung konnten diese Bakterien in den
Milben nachgewiesen werden. Dieser Test verlief sowohl bei Varroa jacobsoni wie bei Acarapis woodi positiv.

Varroa jacobsoni / Acarapis woodi / Zuchtmedium / Fütterung / in vitro

\section{REFERENCES}

Anonymous (1971) Packaged meals for insects. Agric Res 19 (11), 3-4

Bruce WA (1989) Artificial diet for the parasitic mite Pyemotes tritici (Acari: Pyemotidae). Exp Appl Acarol 6, 11-18

Bruce WA, Chiesa F, Marchetti S, Griffiths DA (1988) Laboratory feeding of Varroa jacobsoni Oudemans on natural and artifical diets (Acari: Varroidae). Apidologie 19, 209-218

Bruce WA, Hackett KJ, Shimanuki H, Henegar RB (1991) Bee mites: vectors of honey bee pathogens? In: Proceedings, Apimondia Symposium on Recent Research on Honey Bee Pathology Gent, Belgium Sept 5-7, 1990 (Ritter W, ed) Janssen Pharmaceutica, Beerse, Belgium, 180-182

Butler JF, Hess WR, Endris RG, Holscher $\mathrm{KH}$ (1984) in vitro feeding of Ornithodoros ticks for rearing and assessment of disease transmission. In: Acarology VI (Griffiths DA, Bowman CE, eds) Ellis Horwood Ltd, Chichester

Crystal MM (1986) Artifical feeding of northern fowl mites, Ornithonyssus sylviarum (Canestrini and Fanzago) (Acari: Macronyssidae), through membranes. J Parasitol 72, 550-554

Hagen KS, Tassan RL (1965) A method of providing artificial diets to Chrysopa larvae. $J$ Econ Entomol 58, 999-1000

Smith AW, Needham GR, Page RT (1987) A method for the detection and study of live honey bee tracheal mites (Acarapis woodi Rennie). Am Bee J 127, 433-434

Wharton GW, Cross HF (1957) Studies on the feeding habits of three species of laelaptid mites. J Parasitol 43, 45-50

Whitcomb RF (1983) Culture media for spiroplasmas. Methods Mycoplasmol 1, 147-158 